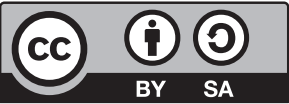

Daria Pańka

\title{
Polish-English Code-Switching in the Language of Polish Facebook Users
}

\begin{abstract}
Social networking services, such as Facebook, are important channels of communication both for monolingual users and for those having various degrees of proficiency in L2, with the latter deploying expression both from L1 and L2. It can, therefore, be presumed that communication on FB plays a role in practicing the use of L2. One of the phenomena that can be examined in relation to that are various forms of code-switching. There is an immense research gap related to Polish-English code-switching appearing on this SNS. To obtain a full picture of the issue, the paper identifies and discusses types, strategies, and functions of Polish-English code-switches found in posts and comments published by Poles on Facebook in 2014-2019. It also indicates possible applications of FB tools and materials including CS in foreign language teaching and learning and shows how Facebook enables "social learning" (Mallia, 2013). The research is based on a corpus constructed by the author of this article. An integrated approach with both qualitative and quantitative methods of analysis is used in the paper. Three main CS types (intrasentential, intersentential, and tag-switching) and strategies (alternation, insertion, and congruent lexicalisation) have been attested in the material. The code-switches mostly indicate in-group membership but also, for example, introduce humor, quotes, and signal a lack of L1 equivalents. The study points out that there are certain relations between the types, strategies and functions. The results of the research are collated with the recent studies on Polish-English and Indonesian-English CS on Facebook.
\end{abstract}

Keywords: code-switching, social media, Facebook, the Polish language, the English language

Social networking services (SNSs), such as Facebook (FB), are recognized as one of the most popular means of communication (Jedamska, 2015), important both for monolingual users and for those having various degrees of proficiency in L2 (with the latter deploying expression both from L1 and 
L2). It can, therefore, be presumed that communication on FB plays a role in practicing the use of L2. This SNS sheds a new light on various language contact phenomena, including code-switches. Switching between non-European languages and English that occurs on Facebook has already been touched upon by various researchers (e.g., Alhazmi, 2016; Dovchin, 2017). However, there is an immense research gap related to Polish-English code-switching (CS) appearing on this social networking service. To obtain a full picture of the issue, the paper identifies and discusses types, strategies, and functions of Polish-English code-switches found in posts and comments published by Poles on Facebook within the last five years (2014-2019). It also indicates possible applications of FB tools and materials including CS in foreign language teaching and learning and shows how Facebook enables the so called social learning (Mallia, 2013). There are few studies referring to the general use of Facebook in education but no discussion addressing it in the light of code-switching was noted. The research is based on a corpus constructed by the present author. An integrated approach with both qualitative and quantitative methods of analysis is used in the paper.

\section{Code-Switching-Theoretical Background}

\section{Concept of Code-Switching}

To start with, code-switching is defined as "the alternate use of two languages or linguistic varieties within the same utterance or during the same conversation" (Hoffman, 1991, p. 110). Certain researchers (e.g., Gonzalez, 2008) argue that CS encompasses only languages - they do not include language varieties in their descriptions of this notion. According to Manfredi, SimeoneSenelle and Tosco (2015), code-switches as well as borrowings are recognized as outcomes of language contact.

Research devoted to code-switching used in spoken or written language may be divided into structural and sociolinguistic discussions (Boztepe, 2003). The former dimension addresses mainly grammatical facets of this phenomenon while the latter direction concentrates on: (1) code-switching as a notion which should be analyzed from the perspective of discourse, (2) the correlation between CS and social factors. Boztepe (2003) adds that those perspectives do not contradict but rather complete each other. Consequently, analyzing both of the dimensions seems to be essential; however, it will not be possible to elaborate on the social aspect of using code-switches by Polish Facebook us- 
ers in the practical part of the present study since $50 \%$ of the authors of the research material have private profiles. As a result, socio-demographic information concerning those speakers is not accessible. Therefore, the paper will concentrate on linguistic issues connected with Polish-English code-switching occurring on Facebook.

When it comes to reasons for code-switching (also referred to as "functions of code-switching"), Walid (2019) lists among them: solidarity, social status, topic, affection, persuasion, the lack of specific vocabulary in a given language. Błasiak (2011) suggests that code-switching results from insufficient linguistic competence of a given speaker concerning one or all of the used languages. However, Bullock and Toribio (2009) present an opposite view: "CS does not represent a breakdown in communication, but reflects the skillful manipulation of two language systems for various communicative functions" (p. 4). In the classroom context, Nordin et al. (2013) highlight that the majority of the surveyed ESL learners show positive attitude to codeswitching. The students claim that CS helps them understand the foreign language (FL).

\section{Differences between Borrowings and Code-Switches}

It is necessary to mention differences between borrowings and codeswitches here since one of the fundamental stages of the present study will be to distinguish between examples of the structures and further analyze only code-switches. Grosjean (2008) proposes a closer look on the form of those two phenomena and the basic difference between them:

A code-switch is a complete shift to the other language for a word, a phrase, or a sentence whereas a borrowing is a morpheme, word, or short expression taken from the less activated language and adapted morphosyntactically (and sometimes phonologically) to the base language. (p. 44)

In practice, one can see that there are also cases of borrowings that do not assimilate into the recipient-language system at all; therefore, they may bear some resemblance to code-switches. In order to detect differences between borrowings and code-switches, I have created a comparison of their features in Table 1. 
Table 1

Differences between borrowings and code-switches

\begin{tabular}{|c|c|c|}
\hline No. & Code-switches & Borrowings \\
\hline 1. & $\begin{array}{l}\text { appear before borrowings } \\
\text { (Halmari, 1997) }\end{array}$ & $\begin{array}{l}\text { appear after code-switches } \\
\text { (Halmari, 1997) }\end{array}$ \\
\hline 2. & $\begin{array}{l}\text { are more restricted when it comes } \\
\text { to their use - individual } \\
\text { (Halmari, 1997) }\end{array}$ & $\begin{array}{l}\text { are less restricted in their use - societal } \\
\text { (Halmari, 1997); established loans reveal a ten- } \\
\text { dency to be "recurrent in the speech of the } \\
\text { individual and widespread across the community" } \\
\text { (Poplack, 2004, p. 590) }\end{array}$ \\
\hline 3. & $\begin{array}{l}\text { are completely unadapted } \\
\text { (Halmari, 1997) }\end{array}$ & $\begin{array}{l}\text { may be adapted in terms of morphology, phonol- } \\
\text { ogy and syntax (Halmari, 1997; Poplack, 2004) }\end{array}$ \\
\hline 4. & $\begin{array}{l}\text { have temporary character } \\
\text { (Manfredi et al., 2015) }\end{array}$ & $\begin{array}{l}\text { do not have temporary character, they are fully } \\
\text { incorporated into the recipient-language system } \\
\text { (Halmari, 1997; Poplack, 1990) }\end{array}$ \\
\hline 5. & $\begin{array}{l}\text { belong to speakers' parole } \\
\text { (Schmidt, 2014) }\end{array}$ & $\begin{array}{l}\text { since languages in contact are integrated, loans } \\
\text { belong to speakers' langue (Schmidt, 2014) }\end{array}$ \\
\hline 6. & $\begin{array}{l}\text { are related to performance } \\
\text { (Panocová, 2015) }\end{array}$ & $\begin{array}{l}\text { are connected with competence } \\
\text { (Panocová, 2015) }\end{array}$ \\
\hline 7. & $\begin{array}{c}\text { cannot be used by monolinguals } \\
\text { (Haspelmath, 2008) }\end{array}$ & $\begin{array}{c}\text { can be used by monolinguals } \\
\text { (Haspelmath, 2008) }\end{array}$ \\
\hline
\end{tabular}

Halmari (1997) observes that borrowings are preceded by code-switching in time. This difference is connected with the process of adaptation. First, foreign linguistic forms are quotes, preserving original shapes, only later, they may become integrated into the recipient language. Haugen (1956, p. 40) specifies the form of code-switching, claiming that it appears when fully unassimilated words are observed in somebody's utterance. As opposed to code-switches, borrowings can be adapted to a given language (Halmari, 1997; Poplack, 2004). Since code-switches are similar to quotes, they have an individual character (Halmari, 1997). Borrowings can be used by a given speaker and then become propagated among a linguistic community and shared by its different members. Code-switches are claimed to be non-recurrent and ephemeral (Manfredi et al., 2015) as opposed to borrowings (Poplack, 2004). Also, code-switches and borrowings may be addressed with reference to the terminology of Chomsky and de Saussure. Temporary code-switches represent parole and performance while borrowings relate to the notion of langue and competence (Panocová, 2015; Schmidt, 2014). Finally, studies show that monolingual speakers are not capable of using code-switches but they can introduce borrowings into their utterances (Haspelmath, 2008). In order to code-switch, a speaker must be at least bilingual. 
After indicating the differences between code-switches and borrowings, it is necessary to establish criteria distinguishing between the structures that will be applied in the present study. They read as follows:

- the degree of assimilation (MacSwan, 1997, pp. 74-75) - it addresses an adaptation level of a given foreign linguistic element in terms of morphology and phonology;

- the frequency of occurrence (Myers-Scotton, 1993, p. 162) - if a foreign form occurs in a relatively large corpus more than twice, one can categorize it as a borrowing.

The criteria will be especially crucial when differentiating between codeswitches and unadapted borrowings because both phenomena are not integrated into the recipient-language system.

\section{Types and Strategies of Code-Switching}

The present section focuses on types and strategies of CS. According to Błasiak (2011), code-switching can appear at different levels of an utterance. In connection with this fact, linguists propose distinct kinds of CS. One of the most popular typologies of code-switching is a division presented by Gonzalez (2008, p. 13). She introduces:

- intersentential code-switching - code-switches occur within different sentences, for example, Czy życzliwa dusza, której p. XYZ dat worksheet, wrzuciłaby go na maila? Much appreciated.

- intrasentential code-switching-code-switches appear within a single sentence, for example, Uczelnio, you are of genious. ${ }^{1}$

Along with the above distinction, Romaine (1995) proposes the third kind of code-switching. She introduces the so called tag-switching, which refers to inserting a tag in a given language into the utterance in another language (Romaine, 1995, p. 122), for example, To jeszcze się zgadamy jak coś, right? (Pańka, 2019, p. 119).

Linguists identify tree strategies of using code-switching that will be addressed in the practical part of the present study (Błasiak, 2011):

- alternation - the change of a code concerns grammar as well as lexicon. Gabryś-Barker (2007) specifies that this strategy concerns introducing whole sentences of a foreign origin.

- insertion - an element from one language is inserted into the structure of another linguistic system. Myers-Scotton (2006, p. 241) adds that "[c]lassic

1 The two listed examples from Pańka (2019, p. 119). The original spelling was preserved and all the proper names were removed from the texts. 
codeswitching includes elements from two (or more) language varieties in the same clause."

- congruent lexicalisation-occurs when a grammatical structure is shared by two languages and elements from both languages can fill it lexically. This kind of CS probably does not involve any structural limitations.

It needs to be also stressed that there are certain rules that limit the occurrence of CS. One of them is equivalence constraint, which states that codeswitching often appears in places where the combination of elements of two different languages does not contravene their grammars (Poplack, 1981).

\subsection{Code-Switching on Facebook}

It is necessary to focus on the state of the art on CS occurring on the most popular social networking service in the world, that is, Facebook (Hamada, 2012). Richter and Koch (2008, pp. 1-2) describe sites of this type in the following way:

Social Networking Services (SNS) are application systems that offer users functionalities for identity management (1) (i.e. the representation of the own person e.g. in form of a profile) and enable furthermore to keep in touch (2) with other users (and thus the administration of own contacts). (Richter \& Koch, 2008, pp. 1-2, emphasis original)

The issue of CS on Facebook has been touched upon by various researchers so far. There are examples of studies that analyze switching between English and the following languages: Arabic (Alhazmi, 2016), Hindi (Jamatia, Gambäck, \& Das, 2015), Indonesian (Syam \& Furwana, 2018), Malay (Bukhari, 2015), Mongolian (Dovchin, 2017), Spanish (Solorio et al., 2014), Thai (Kongkerd, 2015). In the majority of the aforementioned cases, the switching involves English and non-European languages.

To my knowledge, the only studies devoted to Polish-English code-switching appearing on Facebook were conducted by Dąbrowska (2013a, 2013b). ${ }^{2}$ In her research, she addresses types and functions of English code-switches in Polish on the basis of a corpus comprising (only) posts published by native Polish Facebook users in 2012-2013. Taking into account the dynamics of the expansion and evolution of SNSs, an update on the situation of Polish-English CS on Facebook appears to be timely. Aiming to provide current data and their analysis, this study will also hark back to Dąbrowska's results in order to draw

2 The first study is a paper focusing on the CS, the second one is a monograph devoted also to many other issues than this phenomenon. Therefore, later on, only the former discussion will be addressed. 
some conclusions concerning any possible changes in the use of CS over the last years.

Dąbrowska (2013a) does not clearly identify the number of words of the material; however, she informs that it includes 150 posts written by Polish Facebook users. As a consequence, her corpus appears to be much smaller than the one used in the paper. This obviously results from the fact that it has been collected for only one year. When it comes to the CS typology used by Dąbrowska (2013a), the author applies the types proposed by Gonzalez (2008) and Romaine (1995) in her study. Nevertheless, she uses a different term for "tag-switching," that is, "extra-sentential code-switching." As regards the functions of the code-switches, Dąbrowska (2013a, pp. 73-75) provides the following list of them: introducing humor, a light and friendly tone; marking in-group membership, language economy, a lack of equivalent vocabulary in the L1, context specificity, a reinforcement of uttered meanings, quotes, inclusion of others who do not speak the Polish language. Functions of CS in ESL classroom settings seem to be quite different teachers usually apply it to give instruction, feedback, check comprehension, explain grammar and differences between languages as well as discuss tests (Nordin et al., 2013).

While analyzing Pamona-Indonesian code-switching on Facebook, Luke (2015) applies CS types proposed by Hoffman (1991) in her study:

- intra-sentential - occurring within a phrase, a clause or a sentence,

- intra-lexical - appearing within a word,

- involving a change of pronunciation-including changes in phonological structure.

Due to the fact that the code-switches found in the present study do not occur at phonological/morphological levels, the types introduced by Gonzalez (2008) and Romaine (1995) will be used in the paper. Luke (2015) utilizes also reasons for CS provided by Hoffman (1991): talking about a particular topic, quoting somebody else, expressing group identity, strengthening or softening request or command, lexical need, excluding other people when a comment is intended for only a limited audience, being emphatic about something, interjections, repetition used for clarification, intentions of clarifying the speech content for interlocutor. It should be stressed that clarification is frequently mentioned as a reason of CS use in classrooms (Nordin et al., 2013). One may observe that many of Luke's reasons (the first six categories) as well as Walid's motives (2019) mentioned earlier (e.g., solidarity, the lack of vocabulary) correspond to the CS functions proposed by Dąbrowska (2013a).

Syam and Furwana (2018) analyze types of Indonesian-English code-switches on FB and reasons for using them, using only a qualitative method. They utilize the same typology as in the present study; however, they add some new 
motives for CS: the activation of the speakers' speech repertoire, code-switching as style markers, framing discourse, separating feelings from facts, clarifying the speech content for the interlocutor. In the study, I will apply the functions proposed by Dąbrowska (2013a) and add the aforementioned categories by Syam and Furwana (2018) to the division. The results of the present research will be confronted with the findings of the three authors in order to obtain a wider view on CS.

\section{SNSs and Language Learning}

SNSs give a possibility of language learning in formal and informal settings (Mallia, 2013). In the context of the sites, different studies (e.g. Malerba, 2011; Mallia, 2013) highlight the role of social learning, where education entails cooperation. This kind of learning has its roots in social-constructivism, which highlights interaction between people in the development of meaning (Vygotsky, 1978). Mallia (2013, p. 149) paraphrases the stance of Blattner and Fiori (2009, p. 18), claiming that among SNS members, "knowledge is constructed in a community of practice where users 'share similar interest' and have 'pedagogical potentials' [...]."

The SNS environment facilitates studying thanks to integration with others, enhances users' self-confidence, learning motivation and autonomy (Mallia, 2013). Facebook members enjoy studying that involves interaction in English and receiving peer feedback.

Also, the notion of incidental (unintentional) learning should be mentioned here as SNS users may participate in it through observation, social interaction, repetition, and problem solving (McFerrin, 1989; Rogers, 1997). What is crucial here, "[t]he boundaries between learning providers and learners have crumbled: learners have entered the sphere of content production, can create their contents (learner generated content)" (Malerba, 2011, p. 142). There are few studies related to applications of Facebook in FL learning/ teaching. Researchers indicate the following FB tools that might be helpful in this context: Groups (Tafazoli \& Chirimbu, 2013), Notes, Update Status, Upload Photos (Saddhono et al., 2019). 


\section{Material and Methodology of the Study}

\section{Research Material}

The study is based on a corpus constructed by the author of this article. Crystal (2008, p. 17) defines "a corpus" as "[a] collection of linguistic data, either written texts or a transcription of recorded speech, which can be used as a starting-point of linguistic description or as a means of verifying hypotheses about a language [...].” The discussed written material includes Polish posts and comments which were published on Facebook in 2014-2019. It was decided to gather texts only from one SNS in order to obtain homogeneity of the research material. For the corpus, the author selected only public texts ${ }^{3}$ (due to ethical issues) that covered a variety of topics. The material has been constructed for a few years in order to obtain enough data for a valid statistical analysis.

Currently, the corpus consists of 60,000 words; however, it is being successively extended. The author extracted a total of 824 posts and 2,272 comments from Facebook. Any entries including only emojis, emoticons or other images were removed from the material. The register of the language collected is mostly informal. The users are both public and private persons (90 users in total) having, respectively, fan pages and private accounts. They are friends of the author of this article or people followed by her (any texts of random users were removed from the corpus). In order to obtain a balanced material, it was decided to collect texts written by 45 public persons and 45 private users. Thirty of the Facebook users $(33.3 \%)$ are men and 60 of them (66.7\%) are women. English is a foreign language for them. There was no possibility to collect full information concerning their sociodemographic data due to Facebook privacy settings.

\section{Research Methodology}

The methodology of the CS analysis applied in the study involves the following steps:

1. creation of the corpus,

2. searching the corpus for constructions of English origin,

3. division of the constructions into borrowings and code-switches (based on their assimilation degree and occurrence frequency),

4. uploading the corpus into Wordsmith Tools,

5. quantitative and qualitative analyses of the code-switches.

${ }^{3}$ Users can determine a type of access to each post (public/private). 
First, the author systematically built up a corpus by copying posts and comments with correlated metadata from Facebook to a text file. Then, she searched it for constructions of English origin and separated code-switches from borrowings, applying the two criteria: the degree of assimilation and the frequency of occurrence. Next, the author uploaded the corpus in a text file to a program enabling searching patterns in languages, that is, Wordsmith Tools. She studied the instances of CS quantitatively, referring to the length and frequency of the code-switches, and qualitatively, identifying and discussing types, strategies and functions of the code-switching. Thanks to the concordance search option available in the software, she was able to analyze the contexts in which the code-switches appeared. The results are presented in the following section of the paper.

\section{Data Analysis}

\section{Code-Switches Appearing in the Corpus-General Information}

The present part of the paper focuses on the findings of the study. The codeswitches occur 370 times in the corpus. English proper nouns are not counted as the CS instances. Moreover, all of the aforementioned code-switching types have been noticed in the material:

- intrasentential CS- $82 \%$ of the instances (303 code-switches),

- intersentential CS- $11 \%$ of the instances (41 code-switches),

- tag-switching - $7 \%$ of the instances ( 26 code-switches).

Clearly, the first type is the most frequent and the last one appears the least often in the material. Since it is not possible to present all of the code-switches here, the author attempts to provide some examples from each group. All surnames, names of brands and political parties appearing in the material are removed from the instances provided below. Table 2 illustrates the examples of the code-switches ${ }^{4}$ belonging to all of the three types.

\footnotetext{
${ }^{4}$ The code-switches are underlined in the sentences. The original spelling of the posts and comments is preserved.
} 
Table 2

Examples of code-switches found in the corpus

\begin{tabular}{|c|c|}
\hline $\begin{array}{c}\text { Types of } \\
\text { code-switches }\end{array}$ & Examples of code-switches \\
\hline & $\begin{array}{l}\text { 1. Dzień staje się piękniejszy, kiedy w końcu przyjdzie czas na home spa. } \\
\text { 2. Na początek mam do zaprojektowania landing page. } \\
\text { 3. Skoro blogerzy stali się demode dla branży [...] przyszedł czas na influ- } \\
\text { encerów i aktualnie pompowany jest balonik z logo influence marketing. } \\
\text { 4. W każdym innym wypadku środki przeznaczyłbym na inne, sprawdzone } \\
\text { metody digitalowe, jak programmatic. } \\
\text { 5. Mimo, że wielu nazywa nas fit couple, czy „celebrytami”, my po prostu } \\
\text { żyjemy po swojemu. } \\
\text { 6. P.S. Challenge dla Was to nie zaśmiać się podczas oglądania. } \\
\text { 7. XXX - oficjalne family photo z najlepszych czasów dla serwisu. } \\
\text { 8. Żarty się skończyły. Za print screen dziękujemy pani XXX. } \\
\text { 9. Meanwhile w drodze do Białegostoku. Co to się stanęło!? } \\
\text { 10. Well done, XXX. } \\
\text { 11. Przypominamy Wam naszą rozmowę z beauty boys. } \\
\text { 12. Fake, ale głęboko prawdziwy. } \\
\text { 13. Dziś wspomnienie XXX, ulubionego świętego mojej Babci, a więc jako } \\
\text { tribute dla świętej pamięci Babci YYY. } \\
\text { 14. Good job, XXX! } \\
\text { 15. Brakuje mi jeszcze XXX krytykującej YYY. Ale to kwestia czasu; nie- } \\
\text { bawem na } 100 \% \text { jakiś media worker się jej o to zapyta. } \\
\text { 16. Dołączając się do koncertu życzeń, jakby ktoś chciał seminarium } \\
\text { u p. XXX in exchange za seminarium u p. YYY to proszę o info. } \\
\text { 17. Deadline is just a kwestia umowna. }\end{array}$ \\
\hline $\begin{array}{l}\text { Intersentential } \\
\text { code-switches }\end{array}$ & $\begin{array}{l}\text { 1. A nie sam, bo tak sobie postanowiłem. Bullshit! } \\
\text { 2. Widziałam lepszy hit. „Moje oczy zrobione z wody wylewają oceany } \\
\text { pełne łez”. DEAL WITH IT. } \\
\text { 3. Już jutro pierwszy post, żebyśmy mogli lepiej się poznać, i poznać } \\
\text { Wasze potrzeby. Stay tunned. } \\
\text { 4. Morning, peops! Dzisiaj rozpoczynam kolejną serię ze słownictwem [...]. } \\
\text { 5. Wymowa powoduje odruch wymiotny, nawet jeśli są szeptane. Enjoy... if } \\
\text { you dare! } \\
\text { 6. Tu znajdziecie kurs biblioteczny, który trzeba zrobić do nie wiadomo } \\
\text { kiedy. No deadline. } \\
\text { 7. Bitwa o tron. Mission complete. }\end{array}$ \\
\hline Tag-switches & $\begin{array}{l}\text { 1. By the way, znasz ten kawałek? } \\
\text { 2. Pójdziemy tam razem, fine? } \\
\text { 3. Sama to zrobiłam, if you know what I mean. } \\
\text { 4. To be honest, nie znajdziemy nic lepszego. } \\
\text { 5. No więc pisaliśmy już o tym, decyzja została podjęta, indeed. }\end{array}$ \\
\hline
\end{tabular}

The following sections are devoted to the individual types of the codeswitches.

\section{Intrasentential Code-Switches Appearing in the Corpus}

As far as the intrasentential code-switching is concerned, one-word code switches are the most numerous (150 occurrences). The longest code-switches 
include four words; however, they occur the least frequently (ten occurrences). In general, the shorter code-switches are, the more frequently they occur in the corpus. Syam and Furwana (2018) observe that SNS users are usually unaware of intrasentential code-switches. This may be related to the fact that the constructions are mostly short and, as a result, the shift does not disturb the flow of writing. The one-word code-switches represent different parts of speech, such as nouns (e.g., challenge, fake, tribute) as well as adjectives (e.g., programmatic), verbs (e.g., go) and adverbs (e.g., meanwhile), which are less frequent. As far as the last code-switch is concerned, the word (occurring at the beginning of a post) together with an intersentential code-switch appearing at the end of the published text ("Let's see this.") fulfil the function of framing discourse. Syam and Furwana (2018) highlight that such switching that occurs at boundaries attracts and holds the interlocutor's attention. The two-word code-switches create phrases, often involving collocations, as those presented in Table 2, for example, landing page, fit couple, family photo, print screen, well done. Some of the code-switches play the role of separating feelings from facts, where personal opinions are given in one language and facts/proper names are provided in the other, for example, Well done, $X X X$; Good job, $X X X !$. The three- and four-word code-switches usually comprise simple clauses.

Most of the code-switches that include more than one word create authentic phrases and they are not accidental combinations; their components are syntactically adjusted. However, there appear also certain instances of the code-switches which do not contain full grammatical units. This refers to Examples 16 and 17 showed in Table 2. In both of the cases, the code is switched in the middle of a grammatical unit. In the former fragment, instead of introducing a complete English construction "in exchange for" into the post, its author uses "in exchange za" ("za" is a Polish equivalent of "for" in this context) and continues the sentence, utilizing the Polish language. Example 17 seems to be even more interesting. Most of the words in the sentence are of English origin. The switch ends after the article "a," which is a grammatical element not existing in Polish. Notwithstanding the fact, it is put in front of a Polish noun phrase. The whole sentence seems to comply with English patterns since the structure "kwestia umowna" is not inflected. On the basis of the above, it is likely that the sentence was supposed to be written in English in full but the author did not know the English equivalent of the Polish phrase.

As far as the strategies of the code-switching are concerned, two of them have been observed in the instances of the intrasentential code-switching:

1. the insertion of English fragments into the structure of the Polish sentences, for example, Mimo, że wielu nazywa nas fit couple, czy "celebrytami", my po prostu żyjemy po swojemu. 
2. the congruent lexicalization, where Polish and English linguistic elements appear with different frequency, for example, Prawdziwy man i jego woman to wszystko.

The intrasentential code-switches involve lexis connected with everyday life (e.g., snow, nothing personal, romantic, face, family photo, challenge) but also technical vocabulary that can be assigned to three major thematic categories:

- IT (e.g., programmatic, landing page, full version, print screen),

- social media (e.g., fit couple, influence marketing, media worker),

- beauty and cosmetics (e.g., home spa, beauty boys).

Moreover, the intrasentential code-switches belonging to the domains of IT and social media constitute $60 \%$ of all of the code-switches occurring within the sentences. Basically, these constructions closely refer to the discourse in which they appear. It should be also highlighted at this point that some of the introduced terms do not have equivalents in the Polish language as the concepts which they designate seem to be quite new for Poles. That might be one of the reasons for the code-switching. The lack of the counterparts in Polish concerns, for example, the following constructions whose meanings were not noted in dictionaries such as Diki (a Polish-English, English-Polish dictionary, https:// www.diki.pl) and Wielki stownik języka polskiego (a dictionary of the Polish language, https://wsjp.pl): home spa ("domowe spa"), fit couple ("para kochająca sport"), influence marketing ("marketing influencerów"), print screen ("zrzut ekranu"), beauty boys ("chłopcy, którzy się malują"). Apparently, even if any user tried to create his/her own Polish counterparts while writing, some of them could turn out to be quite long (as exemplified by the Polish equivalents of "fit couple" and "beauty boys" above). Consequently, another motive for introducing the English versions in those cases might be the language economy. When it comes to "fit couple," the code-switch may also fulfil the role of a quote since the author of the post writes that many people use this phrase with reference to him and some other person. In fact, the user cites somebody's words despite the lack of quotation marks.

\section{Intersentential Code-Switches Appearing in the Corpus}

The intersentential code-switches do not include technical language. The constructions comprise from one to four words. The most frequent are the two-word structures and the least numerous - the four-word code-switches. The one-word instances represent three parts of speech, that is, nouns (which appear the most often in the material), verbs, and adjectives. The longer codeswitches involve phrases creating, for instance, collocations (Example 7) and

${ }_{5}^{5}$ All the Polish equivalents were proposed by the author of this paper. 
idioms (Example 3). What is important, the second quoted example shows that not all of the analyzed code-switches constitute correct English structures since it contains a spelling mistake (a double ' $n$ ' instead of a single ' $n$ '). The mistake was noticed and notified by other users in the comments-one may observe here an instance of peer correction. However, it was probably of an unintentional character since, as Dąbrowska (2013a, p. 68) mentions, any incorrect structures reveal that "the author's knowledge of English is imperfect," which is an unwanted situation since one is evaluated by other users all the time. Moreover, some of the code-switches cannot be recognized as genuinely existing structures in the English language, for example, Może macie jakąś fajna grę/pomyst na ciekawe zajęcia STOPNIOWANIE PRZYMIOTNIKÓW?? Thanks from the mountain... The underlined construction is also a mistake (a calque). Nevertheless, it does not appear in the material accidentally - the author aims to obtain a humorous effect and a friendly tone by applying a literal translation from Polish into English in her post. This code-switch also shows that the user feels comfortable and safe in the community-it highlights in-group membership. Although the code-switch occurs only once in the corpus, it seems to be a more popular structure. The structure is a manifestation of a linguistic hybrid, called "Ponglish" (Błasiak, 2011). It occurs, for example, in the material collected by Błasiak (2011) that consists of utterances of Poles living in Great Britain. As a consequence, this code-switch seems to be multifunctional-it can also fulfil the role of a quote.

One can notice that in most of the cases, the code-switches occur at the end of the posts or comments (as in Examples 1, 2, 3, 5, 6, 7 provided in Table 2). This probably results from the fact that those English elements serve as an addition to the main content and, in some of the instances, as a summary. They take the form of questions, exclamations, and imperative sentences. The aforementioned fragments may be contrasted with the following example: Morning, peops! Dzisiaj rozpoczętam kolejna serię ze stownictwem [...]. Here English "Morning, peops!" appears at the beginning of a post. However, still, the part conveying the main content is written in Polish - the English elements fulfil only the function of a short greeting. Moreover, one can note that this code-switch includes very informal language. This informality is strengthened by the use of an exclamation mark (in fact, typical of greetings). Apart from the reinforcement of the uttered meanings, other functions of the code-switch may be observed. It indicates the context specificity - the author of the post (a teacher) manages a fan page devoted to learning English; therefore, the free use of Polish-English code-switches seems to be predictable here. Also, the mentioned code-switch shows in-group membership (English is a common interest of the user and her followers) and constitutes a style marker-indicates casual relations between the teacher and the users following her. 
As far as the other exclamations are concerned, one of the users (a public person) includes in his post the impolite word "bullshit." Obviously, by using an exclamation mark, he tries to reinforce the uttered meaning and draw special attention to his words. As Dąbrowska (2013a) mentions, such cases carry an expressive value. Interestingly enough, at the same time, the author of the post aims at introducing a lighter tone of the impolite word by writing it in English, not in Polish. The code switch may be recognized as a style marker, showing sincere and open relations between the author and his followers. The user even addresses the people observing him in the following way: "Wy, jako moi internetowi przyjaciele" ("You, as my Internet friends").

In one of the posts (“Szczęśliwego Dnia Kobiet! Happy Women's Day!”), the function of the inclusion of others who do not speak the Polish language was noticed. The text was created in two versions by a very popular public person in Poland who has also followers from other countries and wanted to reach as many users as possible with her wishes.

Since the code-switches of this type appear in separate sentences, they do not interfere with the Polish fragments in terms of grammar. As regards the strategy of the code-switching, the alternation of the linguistic codes may be observed.

\section{Tag-Switches Appearing in the Corpus}

As has been mentioned earlier, the tag-switches are the least frequent in the corpus. They include from one to six words. The one-word code-switches are the most numerous (seven occurrences) and the six-word code-switches appear the least frequently (only one occurrence). The instances of this CS type involve adverbs (e.g., by the way, indeed), adjectives (e.g., fine) and more complex structures, such as subordinate clauses (e.g., to be honest; if you know what I mean). The code-switches occur both at the beginning and at the end of the sentences, serving as additional elements, interjections. They do not convey any meaningful content and include any technical terms. However, as Syam and Furwana (2018) rightly notice, tag-switches may be used due to their attractiveness and popularity. This is the case when it comes to the above examples (utterances including such fragments may be frequently noticed, for example, in English-language films/series). Moreover, most of the code-switches fulfil the functions of introducing a light and friendly tone and marking ingroup membership (e.g., by the way and if you know what I mean were used in a conversation between English philology students).

The English elements do not interfere with the grammar of the Polish fragments. This is related to the character of the tag-switches-they include full grammatical units and are always separated from the rest of the words 
in the sentences by commas. As far as the strategy of the code-switching is concerned, the insertion of the English elements into the Polish sentences may be observed.

\section{Concluding Remarks}

To conclude, the contemporary use of English by Polish Facebook users is visible, for example, in the form of code-switches. The informal register of the language used in the present material naturally encourages the use of English since, as Dąbrowska (2013a, p. 64) notices, Facebook gives its users a "sense of safety and acceptance" and a space for interaction with others. As a result, this SNS creates a great environment for learning and practicing English in various forms in users' daily lives.

The research demonstrates that there is a considerable research gap related to Polish-English code-switching appearing on Facebook. The results of the paper are confronted with the findings of Dąbrowska (2013a) and Syam and Furwana (2018). The code-switching analyzed in this research appears at different grammatical levels and uses distinct patterns - it includes all of the three major CS types and strategies. The study shows that the types and strategies are closely related, which results from the character of the individual types. In the intrasentential CS, alternation is not possible since it requires introducing whole sentences - obviously, it occurs as the only strategy in the intersentential CS. In the tag-switching, which includes single words/fixed constructions within sentences, only insertion was possible. As regards the functions, the lack of L1 vocabulary appears only in the intrasentential CS as it frequently involves the use of terms. The reinforcement of the uttered meanings is typical of the intersentential CS - the easiest way to strengthen the expression of a given text was to code-switch in a separate sentence. As the tag-switches are only interjections, they reduce the formality of the sentence.

The majority of the code-switches appear within sentences; the tag-switches are the least frequent. In Dąbrowska's study (2013a), the tag-switches also constitute the smallest group; however, the distribution of the intra- and intersentential code-switches is similar. A CS type which does not occur in both of the studies is code-switching within the word level (noticed in Syam and Furwana, 2018). In the present paper, most of the one-word code-switches include nouns (in the study of Syam and Furwana, 2018, some of the users utilize English conjunctions in their texts - they are not present here). Within the multi-word constructions of English origin, distinct syntactic structures such as collocations and idioms were found. When it comes to the complex code-switches, there is 
no limit concerning sentence types - they contain not only statements but also questions, exclamations, and commands. This means that the users feel freely using CS and probably have a good command of English.

In most of the cases, the authors of the posts and comments create genuinely existing structures of foreign origin and stick to the equivalence constraint (similar results in Dąbrowska, 2013a). This results from the users' willingness to be understood by their interlocutors. English is their foreign language; therefore, they make mostly safe choices. As Dąbrowska (2013a) highlights, the reason for that is a fear of making mistakes. The users try to be cautious since in written communication, the incorrect forms are especially visible. However, there are certain single artificially created constructions that aim, for example, at bringing humor into the conversations and structures including spelling mistakes - some departures from standard English also appear in Dąbrowska's study (2013a). Quite different results were obtained by Syam and Furwana (2018) - most of the analyzed users do not follow the grammatical rules.

The function of marking in-group membership appears the most frequently (similar results in Luke, 2015, but different in Dąbrowska, 2013a, where humorous undertones occur the most often), which suggests that the solidarity with other users is particularly important for the FB members. A command of English seems to be particularly important for any user aiming to fully identify with the Facebook community in linguistic terms. Some of the intrasentential code-switches include technical vocabulary related to IT, social media, beauty and cosmetics. These are the spheres of our life which appear to be rapidly developing nowadays. Some of the code-switches currently do not have equivalents in Polish. The issue of lexical topics related to these spheres should probably be taken into consideration while establishing FL teaching curricula. Code-switching fulfils also many other functions in the corpus: language economy, context specificity, style marker, reinforcing the uttered meanings, introducing a light and friendly tone or quotes, separating feelings from facts, framing discourse. Consequently, the code-switching may be recognized as a useful linguistic strategy. All of the functions of Dabrowska (2013a) were noticed in the paper; two of the motives of Syam and Furwana (2018) were not observed: the activation of the speakers' speech repertoire and clarifying the speech content for the interlocutor. The comparison of the studies shows that the character of code-switching depends on a language (more differences were noticed between the present paper and the research of Syam and Furwana, 2018).

Facebook might serve as a FL teaching/learning tool. First, as has been noticed, the posts and comments published on this SNS include linguistic mistakes not only within the code-switches. Teachers can use the material in an error correction task, for example, Polish students could identify mistakes in English fragments and students learning Polish as a foreign language could look for mistakes in Polish fragments. Second, there are a number of fan pages 
founded, for example, by teachers that spread knowledge about languages. The use of code-switches by public persons (who might be a kind of role models) can encourage the use of similar structures by their followers as "fans of celebrities may seek to imitate or impersonate a certain celebrity's behavior in order to increase their own personal self-esteem" (Min, 2019). Moreover, the users may also join school-, interest- or even job-related groups, where they can practice foreign languages. In such groups and outside of them, Facebook members may learn not only from the teacher ${ }^{6}$ (school groups) but also from each other by active discussion with native and non-native speakers, sharing ideas in L2, cooperation, identifying others' linguistic mistakes, providing peer feedback and establishing the understanding of new foreign terms (social learning). All of these can be facilitated by the following FB tools: Update Status, Comment, Video Chat, Instant Message, Facebook Apps, Facebook Quiz. The learning may be incidental - the users can enrich their foreign vocabulary by reading posts/comments of other people that include CS. The observation of new lexical items in such a form may arise interest and engagement in verifying their meaning. In general, Facebook can be identified as "Personal Learning Environment" (Siemens, 2006) - users create and manage their own learning spaces there, for example, they decide which linguistic fan pages to follow, which linguistic groups to join.

Due to the limitations related to the Facebook privacy settings, it is recommended that further research should endeavor to gain socio-demographic data on users of this SNS, for example, by means of a questionnaire. It would be particularly helpful to investigate the code-switches in the light of the users' command of English. To date, there has been disagreement on whether CS results from insufficient or high linguistic competence of speakers using different languages. This issue can be identified as another research gap that should be addressed in further studies.

\section{References}

Alhazmi, A. (2016). Linguistic aspects of Arabic-English code switching on Facebook and radio in Australia. International Journal of Applied Linguistics \& English Literature, 5(3), 184-198.

Aranoff, M., \& Rees-Miller, J. (2003). The handbook of linguistics. Blackwell Publishers: Oxford.

${ }^{6}$ The use of CS by teachers on FB groups fulfils quite different functions than the ones indicated in the study - they are beyond the scope of the paper. 
Blattner, G., \& Fiori, M. (2009). Facebook in the language classroom: Promises and possibilities. International Journal of Instructional Technology and Distance Learning, 6, 17-28.

Błasiak, M. (2011). Dwujęzyczność i Ponglish: zjawiska językowo-kulturowe polskiej emigracji $w$ Wielkiej Brytanii. Kraków: Collegium Columbinum.

Boztepe, E. (2003). Issues in code-switching: Competing theories and models. Working Papers in TESOL \& Applied Linguistics, 3(2), 1-27.

Bukhari, N., Anuar, A., Khazin, K., \& Aziz, T. (2015). English-Malay code-mixing innovation in Facebook among Malaysian university students. Researchers World, 6(4), 1-10.

Bullock, B. E., \& Toribio, A. J. (2009). Themes in the study of code-switching. In B. E. Bullock \& A. J. Toribio, (Eds.), The Cambridge handbook of linguistic code-switching (pp. 1-17). Cambridge: Cambridge University Press.

Crystal, D. (2008). A dictionary of linguistics and phonetics (6th ed.). Malden: Blackwell.

Dąbrowska, M. (2013a). Functions of code-switching in Polish and Hindi Facebook users' posts. Studia Linguistica Universitatis Iagellonicae Cracoviensis, 130, 63-84.

Dąbrowska, M. (2013b). Variation in language. Faces of Facebook English. Frankfurt am Main: Peter Lang.

Diki. Multimedialny stownik angielskiego online. Accessed September 1, 2019. Retrieved from: http://www.diki.pl/

Dovchin, S. (2017). The role of English in the language practices of Mongolian Facebook users. English Today 130, 33(2), 16-24.

Gabryś-Barker, D. (2007). Zjawisko wtrąceń z języka drugiego u osoby dwujęzycznej: charakterystyka i funkcje. In W. Chłopicki (Ed.), Komunikacja międzykulturowa; perspektywy badań interdyscyplinarnych (pp. 293-305). Kraków: Wydawnictwo Tertium.

Gardner-Chloros, P. (2011 [2009]). Code-switching. Cambridge: Cambridge University Press.

Gonzalez, J. (Ed.). (2008). Encyclopedia of bilingual education. California: SAGE Publications, Inc.

Grosjean, F. 2008. Studying bilinguals. Oxford: Oxford University Press.

Halmari, H. (1997). Government and codeswitching: Explaining American Finnish. Amsterdam: John Benjamins.

Hamada, M. (2012). A Facebook project for Japanese university students: does it really enhance student interaction, learner autonomy, and English abilities? In L. Bradley \& S. Thouësny (Eds.), EUROCALL Conference Proceedings: Using, Learning, Knowing (pp. 104-110). Dublin-Voillans: Research-publishing.net.

Haspelmath, M. (2008). Loanword typology: Steps toward a systematic cross-linguistic study of lexical borrowability. In T. Stolz, D. Bakker, \& R. Salas Palomo (Eds.), Aspects of language contact: New theoretical, methodological and empirical findings with special focus on Romancisation processes (pp. 43-62). Berlin and New York: Mouton de Gruyter.

Haugen, E. (1956). Bilingualism in the Americas: A bibliography and research guide. Alabama: University of Alabama Press.

Hoffman, Ch. (1991). An introduction to bilingualism. New York: Longman.

Jamatia, A., Gambäck, B., \& Das, A. (2015). Part-of-speech tagging for code-mixed EnglishHindi Twitter and Facebook chat messages. In R. Mitkov, G. Angelova, \& K. Bontcheva, (Eds.), Proceedings of recent advances in natural language processing (pp. 239-248). Hissar: Incoma.

Jedamska, K. (2015). Portale społecznościowe - nowe narzędzie komunikacji politycznej. Accessed September 1, 2019. Retrieved from: http://apcz.umk.pl/czasopisma/index.php/ TEST_UMK/article/view/5866

Kongkerd, W. (2015). Code switching and code mixing in Facebook conversations in English among Thai users. Executive Journal, 35(1), 126-132. 
Luke, J. (2015). The use of code-mixing among Pamonane in Parata Ndaya closed-group Facebook. Jurnal LINGUA CULTURA, 9(1), 4-46.

MacSwan, J. (1997). A minimalist approach to intrasentential code switching: SpanishNahuatl bilingualism in central Mexico (Doctoral dissertation). Los Angeles: University of California. Accessed September 1, 2019. Retrieved from: http://www.public.asu. edu/ macswan/diss.html

Malerba, M. (2011). Social networking in second language learning. In Proceedings of PLE Conference 2011 (pp. 1-6). Southampton: PLE.

Mallia, G. (2013). The social classroom: Integrating social network use in education. Hershey: IGI Global.

Manfredi, S., Simeone-Senelle, M. C., \& Tosco, M. (2015). Language contact, borrowing and codeswitching. In A. Mettouchi, M. Vanhove, \& D. Caubet (Eds.), Corpus-based studies of lesser-described languages: the CorpAfroAs corpus of spoken AfroAsiatic languages. Studies in Corpus Linguistics 67 (pp. 283-308). Amsterdam: John Benjamins.

McFerrin, K. (1999). Incidental learning in a higher education asynchronous online distance education course. In SITE 99: Society for Information Technology \& Teacher Education International Conference Proceedings (pp. 2-7). Charlottesville, VA: Association for the Adputing in Education.

Min, J., Chang, H. Jai, T., \& Ziegler, M. (2019). The effects of celebrity-brand congruence and publicity on consumer attitudes and buying behaviour. Fash Text, 6(10). https://doi.org/10.1186/s40691-018-0159-8

Myers-Scotton, C. (1993). Social motivations for codeswitching. Evidence from Africa. Oxford: Clarendon Press.

Myers-Scotton, C. (2006). Multiple voices: an introduction to bilingualism. Oxford: Blackwell Publishing.

Nordin, N., Ali, F., Zubir, S., \& Sadjirin, R. (2013). ESL learners reactions towards codeswitching in classroom setting. In I. Ismail, S. Rahman, N. Noordin, \& S. Mustafa (Eds.), Procedia-social and behavioral sciences (Vol. 90, pp. 478-487). https://doi.org/10.1016/j.sbspro.2013.07.117

Panocová, R. (2015). Categories of word formation and borrowing. an onomasiological account of neoclassical formations. Newcastle upon Tyne: Cambridge Scholars Publishing.

Pańka, D. (2019). Hejting, trolling i unboxing - o współczesnym wpływie języka angielskiego na język polski używany na Facebooku. In V. Tanaś \& W. Welskop (Eds.), Mass media we współczesnym świecie (pp. 113-123). Łódź: Wydawnictwo Naukowe Wyższej Szkoły Biznesu i Nauk o Zdrowiu.

Poplack, S. (1981). Syntactic structure and social function of codeswitching. In R. P. Duran (Ed.), Latino Language and Communicative Behaviour (pp. 169-184). New Jersey: Ablex Publishing Corporation.

Poplack, S. (2004). Code-switching. In U. Ammon, N. Dittmar, K. J. Mattheier \& P. Trudgill (Eds.), Sociolinguistics/Soziolinguistik: An international handbook of the science of language (pp. 589-596). Berlin: Walter de Gruyter.

Richter, A., \& Koch, M. (2008). Functions of social networking services. In P. Hassanaly, A. Ramrajsingh, D. Randall, P. Salembier \& M. Tixier (Eds.), Proceedings of the 8th International Conference on the Design of Cooperative Systems (pp. 87-98). Carry-leRouet: Institut d'Etudes Politiques d'Aix-en-Provence.

Rogers, A. 1997. Learning: Can we change the discourse? Adults Learning, 8(5), 116-117.

Romaine, S. (1995). Bilingualism. Oxford: Blackwell Publishers. 
Saddhono, K., Hasibuan, A., \& Bakhtiar, M. (2019). Facebook as a learning media in TISOL (Teaching Indonesian to Speakers of Other Languages) learning to support the independency of foreign students in Indonesia. Journal of Physics: Conference Series, 1254(1), 1-6.

Schmidt, A. (2014). Between the languages: code-switching in bilingual communication. Hamburg: Anchor Academic Publishing.

Siemens, G. (2006). Learning or management systems? A review of learning management system reviews. Learning Technologies Centre (24 November). Retrieved from: http://www. connectivism.ca/? $\mathrm{p}=243$

Solorio, T., Blair, E., Maharjan, S., Bethard, S., Diab, M., Gonheim, M., Hawwari, A., AlGhamdi, F., Hirshberg, J., Chang, A., \& Fung, P. (2014) Overview for the first shared task on language identification in Code-switched data. In M. Diab, J. Hirschberg, P. Fung, \& T. Solorio (Eds.), Proceedings of the First Workshop on Computational Approaches to Code-Switching (pp. 62-72). Doha: Association for Computational Linguistics.

Syam, A., \& Furwana, D. (2018). An analysis of code switching in Facebook: A discourse approach. Journal on English Language Teaching \& Learning Linguistics and Literature, $5(1), 1-16$.

Tafazoli, D., \& Chirimbu, S. (2013). Social networking: Using Facebook in teaching English idioms. World of Linguistics and Communication, 1(30), 1-6.

Vygotsky, L. S. (1978). Mind in society. Cambridge, MA: Harvard University Press.

Walid, R. M. (n.d.). Why do people code switch: a sociolinguistics approach. Arab Open University. Retrieved August 22, 2019, from http://www.academia.edu/2649532/Why_do_ People_Code-switch_A_Sociolinguistic_Approach.

Wielki slownik języka polskiego. Accessed September 1, 2019. Retrieved from: https://www. wsjp.pl.

Daria Pańka

\section{Codeswitching zwischen Polnisch und Englisch in der Sprache polnischer Facebook-Nutzer}

\section{Zusammenfassung}

Social Media, wie Facebook, sind wichtige Kommunikationswege sowohl für einsprachige Anwender als auch für Nutzer mit verschiedenen Fremdsprachenkenntnissen (die letzteren übernehmen die Strukturen der Mutter- und Fremdsprache in die Konversation). Im Resultat kann man annehmen, dass die Kommunikation via Facebook eine gewisse Rolle bei der Verwendung von Fremdsprachen spielt. Einen der Aspekte, der in dieser Hinsicht analysiert werden kann, bilden verschiedene Formen von Codeswitching. In Bezug auf das Codeswitching zwischen Polnisch und Englisch, das in diesem sozialen Netzwerk vorkommt, besteht eine wesentliche Forschungslücke. Für einen kompletten Überblick über das dargestellte Problem werden im vorliegenden Artikel an angeführten polnisch-englischen Beispielen bestimmte Typen, Strategien und Funktionen von Codeswitching in Posts und Kommentaren, die von polnischen Facebook-Nutzern in den Jahren 2014-2019 erstellt wurden, identifiziert und erläutert. Darüber hinaus wird im Text auf die Anwendungsmöglichkeiten von FacebookTools und Materialien zum Codeswitching bei dem Fremdsprachenlehren und -lernen hingewiesen und der Aspekt des „sozialen Lernens“ (Mallia, 2013) mittels Facebook angesprochen. 
Die Untersuchung basiert auf einem Korpus, das von der Autorin des vorliegenden Artikels entwickelt wurde. In der Untersuchung wurde eine integrative - d.h. qualitative und quantitative Methode eingesetzt. Im analysierten Material lassen sich drei Haupttypen (satzinterner, satzübergreifender, parenthetischer) und -strategien (Alliteration, Parenthese, entsprechende Umstellung von Lexemen) des Sprachcodeswitching unterscheiden. Das Codeswitching deutet hauptsächlich auf die Zugehörigkeit zur bestimmten Gruppe hin, kann aber auch Humor bzw. ein Zitat in die Aussage einleiten oder das Fehlen von Äquivalenten in der Muttersprache signalisieren. Aus dem Artikel ergibt sich, dass es gewisse Abhängigkeiten zwischen den Typen, Strategien und Funktionen des Codeswitching gibt. Die Resultate der betreffenden Analyse werden mit Ergebnissen der neuesten Untersuchungen über das polnisch- und indonesischenglische Codeswitching auf Facebook zusammengestellt.

Schlüsselwörter: Codeswitching, Social Media, Facebook, Polnisch, Englisch 